\title{
Erratum to: Herbivory strongly influences among-population variation in reproductive output of Lythrum salicaria in its native range
}

\author{
Lina Lehndal ${ }^{1}$ Peter A. Hambäck ${ }^{2}$ Lars Ericson $^{3} \cdot$ Jon Ågren $^{1}$
}

Published online: 12 February 2016

(C) Springer-Verlag Berlin Heidelberg 2016

\section{Erratum to: Oecologia DOI 10.1007/s00442-015-3520-2}

Unfortunately, Tables 1 and 2 were incorrectly published in the original article. The corrected Tables 1 and 2 are given below:

The online version of the original article can be found under doi:10.1007/s00442-015-3520-2.

Lina Lehndal

lina.lehndal@ebc.uu.se

1 Plant Ecology and Evolution, Department of Ecology and Genetics, Evolutionary Biology Centre, Uppsala University, Norbyvägen 18 D, 75236 Uppsala, Sweden

2 Department of Ecology, Environment and Plant Sciences, Stockholm University, 10691 Stockholm, Sweden

3 Department of Ecology and Environmental Science, Umeå University, 90187 Umeå, Sweden 
Table 1 Effect of population on damage from herbivores and reproductive success of control plants in nine natural Lythrum salicaria populations in the Skeppsvik archipelago, N. Sweden

\begin{tabular}{llcrl}
\hline Response variable & $d f_{\text {num }}, d f_{\text {den }}$ & MS/residual deviance & \multicolumn{1}{c}{$F / \chi^{2}$} & $P$ \\
\hline Proportion of leaf area removed & 8,490 & 1.80 & 54.65 & $<\mathbf{0 . 0 0 0 1}$ \\
Proportion with meristem damage & 8,497 & 502.11 & 192.22 & $<\mathbf{0 . 0 0 0 1}$ \\
Proportion flowering & 8,497 & 476.59 & 199.88 & $<\mathbf{0 . 0 0 0 1}$ \\
\# Flowers per reproductive plant & 7,187 & 3.91 & 13.22 & $<\mathbf{0 . 0 0 0 1}$ \\
\# Seeds per flower & 7,186 & 3.95 & 14.94 & $<\mathbf{0 . 0 0 0 1}$ \\
Female reproductive success & 8,522 & 85.36 & 45.45 & $<\mathbf{0 . 0 0 0 1}$ \\
\hline
\end{tabular}

Effects on proportion of leaf area removed, number of flowers per reproductive plant, number of seeds per flower, and female reproductive success (proportion of flowering plants $\times$ the number of flowers per reproductive plant $\times$ the number of seeds per flower) were analyzed with one-way ANOVA (MS and $F$ given), whereas effects on proportion of plants with meristem damage and on proportion flowering were analyzed with generalized linear models (residual deviance and $\chi^{2}$ given). Significant effects are in bold

Table 2 Effects of population and herbivore removal on damage from herbivores and reproductive success in nine natural Lythrum salicaria populations

\begin{tabular}{|c|c|c|c|c|c|}
\hline Response variable & Source & $d f_{\text {num }}, d f_{d e n}$ & MS/residual deviance & $F / \chi^{2}$ & $P$ \\
\hline \multirow[t]{3}{*}{ Proportion of leaf area removed } & Population & 8,770 & 1.80 & 81.76 & $<0.0001$ \\
\hline & Herbivore removal & 1,770 & 2.54 & 115.69 & $<0.0001$ \\
\hline & Pop $\times$ herb rem & 8,770 & 0.66 & 29.94 & $<0.0001$ \\
\hline \multirow[t]{3}{*}{ Proportion with meristem damage } & Population & 8,788 & 809.01 & 146.98 & $<0.0001$ \\
\hline & Herbivore removal & 1,787 & 572.15 & 236.86 & $<0.0001$ \\
\hline & Pop $\times$ herb rem & 8,779 & 546.27 & 25.88 & 0.0011 \\
\hline \multirow[t]{3}{*}{ Proportion flowering } & Population & 8,788 & 880.91 & 217.27 & $<0.0001$ \\
\hline & Herbivore removal & 1,787 & 844.06 & 36.85 & $<0.0001$ \\
\hline & Pop $\times$ herb rem & 8,779 & 827.98 & 16.08 & 0.041 \\
\hline \multirow[t]{3}{*}{ \# Flowers per reproductive plant } & Population & 7,328 & 3.91 & 12.80 & $<0.0001$ \\
\hline & Herbivore removal & 1,328 & 0.28 & 0.93 & 0.34 \\
\hline & Pop $\times$ herb rem & 7,328 & 0.11 & 0.36 & 0.92 \\
\hline \multirow[t]{3}{*}{ \# Seeds per flower } & Population & 7,326 & 2.22 & 10.98 & $<0.0001$ \\
\hline & Herbivore removal & 1,326 & 6.15 & 30.42 & $<0.0001$ \\
\hline & Pop $\times$ herb rem & 7,326 & 1.46 & 7.22 & $<0.0001$ \\
\hline \multirow[t]{3}{*}{ Female reproductive success } & Population & 8,805 & 85.36 & 36.94 & $<0.0001$ \\
\hline & Herbivore removal & 1,805 & 17.92 & 7.75 & $\mathbf{0 . 0 0 5 5}$ \\
\hline & Pop $\times$ herb rem & 8,805 & 4.74 & 2.05 & 0.038 \\
\hline
\end{tabular}

Effects on proportion of leaf area removed, number of flowers per reproductive plant, number of seeds per flower, and female reproductive success (proportion of flowering plants $\times$ the number of flowers per reproductive plant $\times$ the number of seeds per flower) were analyzed with twoway ANOVA (MS and $F$ given), whereas effects on proportion of plants with meristem damage and proportion flowering were analyzed with generalized linear models (residual deviance and $\chi^{2}$ given). Significant effects are in bold 